\title{
Analisis Penghambat Perkembangan Praktek Akuntansi di Badan Usaha Milik Desa
}

\author{
Ade Palupi ${ }^{1}$ \\ ${ }^{1}$ Program studi Akuntansi, Fakultas Ekonomi dan Bisnis, Universitas Al Azhar Indonesia, \\ Komplek Masjid Agung Al-Azhar, Jl. Sisingamangaraja, Kebayoran Baru, Jakarta Selatan 12110 \\ Penulis untuk Korespondensi/E-mail: ade.palupi@uai.ac.id
}

\begin{abstract}
This study analyzes why a Village Owned Enterprise (BUMDes) has not been able to practice accounting by applicable accounting standards. This research applies a case study using BUMDes MW located in a village in West Java. Data is obtained by interviews, observations, and documentation. The data were analyzed with an interpretive approach and used Bourdieu's capital theory (1986) as a theoretical framework. The results of the study are BUMDes MW has not been able to practice accounting by accounting standards because of the limitations of ownership of three types of capital, namely economic capital, cultural capital, and social capital. BUMDes still relies on its financial capital from the village government. Limited knowledge, skills, and systems on accounting are cultural capital factors that have not been optimally owned by BUMDes. That networking with external parties to help in the implementation of accounting also has not been done by BUMDes is a social capital factor that BUMDes does not yet have. The condition of the limitations of these three capitals also brings the impact of BUMDes financial management has not been implemented properly. Thus, BUMDes' position in implementing the village economic empowerment program is still not strong in its social space.
\end{abstract}

Keyword: Accounting, BUMDes, Bourdieu, Village

\begin{abstract}
Abstrak
Penelitian ini menganalisa mengapa sebuah Badan Usaha Milik Desa (BUMDes) belum mampu mempraktekkan akuntansi sesuai dengan standar akuntansi yang berlaku. Penelitian bersifat studi kasus dengan menggunakan BUMDes MW yang terletak di sebuah Desa di Jawa Barat. Data diperoleh dengan wawancara, observasi dan dokumentasi. Data dianalisa dengan pendekatan interpretatif dan menggunakan teori modal Bourdieu (1986) sebagai kerangka teori. Hasil penelitian adalah BUMDes MW belum maтрu mempraktekkan akuntansi yang sesuai dengan standar akuntansi karena keterbatasan kepemilikan tiga jenis modal, yaitu modal ekonomi, modal budaya dan modal sosial. BUMDes masih menggantungkan modal keuangannya kepada pemerintah desa. Pengetahuan, ketrampilan dan sistem akuntansi yang terbatas merupakan faktor modal budaya yang belum secara optimal dimiliki oleh BUMDes. Hubungan kerjasama dengan pihak luar untuk membantu dalam pelaksanaan akuntansi juga belum dilakukan oleh BUMDes. Hal ini merupakan faktor modal sosial yang belum dimiliki oleh BUMDes. Kondisi keterbatasan ketiga modal ini juga membawa dampak manajemen keuangan BUMDes belum terlaksana dengan baik. Dengan demikian, posisi BUMDes dalam melaksanakan program pemberdayaan ekonomi desa masih belum kuat di lingkungan desa tempat BUMDes tersebut berada.
\end{abstract}

Kata kunci: Akuntansi, BUMDes, Bourdieu, Desa 


\section{PENDAHULUAN}

\section{Latar Belakang}

Salah satu fokus Nawacita adalah membangun negara yang dimulai dari daerah pedesaan. Hal ini sesuai dengan amanat Undang-undang Nomor 6 Tahun 2014 tentang Desa yang merupakan dasar bagi program-program pemberdayaan masyarat desa. Untuk mendukung peningkatan pembangunan di desa, Pemerintah di bawah kepemimpinan Presiden Joko Widodo, meningkatkan anggaran transfer ke desa dari tahun ke tahun. Dana desa yang dialokasikan oleh pemerintah pusat meningkat dari tahun ke tahun. Alokasi anggaran desa sebesar Rp 46,9 triliun di tahun 2016 meningkat menjadi Rp 60 triliun di tahun 2017. Bahkan pada saat pandemik Covid-19, anggaran dana desa untuk tahun 2020 sebesar Rp72 triliun, yang meningkat dari sejumlah $\mathrm{Rp} 70$ triliun di tahun 2019. Dana desa ini ditujukan untuk meningkatkan kualitas hidup dan pendapatan masyarakat desa melalui program pemberdayaan dan pengembangan potensi ekonomi desa sehingga daya beli mereka bertambah kuat (Indonesia, 2020; Viska, 2017)

Selain dari pemerintah pusat, pemerintah desa juga menerima bantuan keuangan dari pemerintah propinsi dan pemerintah kabupaten melalui alokasi dana desa dan dana bagi hasil pajak dan retribusi daerah. Keseluruhan dana yang didapat oleh pemerintah desa, harus diakui ke dalam Anggaran Pendapatan dan Belanja Desa (APBDes) dan digunakan untuk meningkatkan ketahanan ekonomi, sosial dan budaya bagi masyarakat desa.

Salah satu upaya untuk meningkatkan perekonomian desa adalah dengan mendirikan Badan Usaha Milik Desa (BUMDes). Berdasarkan Pasal 1, butir 2 (Peraturan Menteri Desa, Pembangunan, Daerah Tertinggal, Dan Transmigrasi Nomor 4 Tahun 2015 Tentang Pendirian, Pengurusan Dan Pengelolaan, Dan Pembubaran Badan Usaha Milik Desa, 2015), BUMDes, adalah badan usaha yang seluruh atau sebagian besar modalnya dimiliki oleh desa melalui penyertaan secara langsung yang berasal dari kekayaan desa yang dipisahkan guna mengelola aset, jasa pelayanan, dan usaha lainnya untuk sebesar-besarnya kesejahteraan masyarakat desa.

Pasal 17 pada peraturan yang sama menyatakan bahwa modal awal BUMDes adalah dari penyertaan modal desa yang berasal dari alokasi APBDes. Seterusnya modal BUMDes selain dari penyertaan modal pemerintah desa juga berasal dari penyertaan modal masyarakat desa dan keuntungan BUMDes.

Berdasarkan kedua pasal dari peraturan tentang desa tersebut, dapat disimpulkan bahwa BUMDes merupakan sarana yang digunakan oleh pemerintah desa untuk meningkatkan ketahanan ekonomi desa. Sampai tahun 2019, beberapa BUMDes sudah menunjukkan keberhasilannya dalam meningkatkan perekonomian desa. Sebagai contoh, BUMDes Karangkandri Sejahtera di Desa Karangkandri, Kecamatan Kesugihan, Kabupaten Cilacap yang menyuplai batu bolder untuk Pembangkit Listrik Tenaga Uap; BUMDes Tirta Mandiri di Desa Ponggok, Kecamatan Polan, Kabupaten Klaten yang mengelola kolam renang alami untuk tujuan wisata (Aryadjihs, 2017). BUMDES Maju Desa Ujunggebang, kabupaten Indramayu sukses mengembangkan usaha di bidang air kesehatan/isi ulang, pengelolaan keuangan, dan pariwisata Pantai Plentong (Purnomo, 2018). Serta, BUMDes Cisantana di Desa Cisantana, Kecamatan Cigugur, Kabupaten Kuningan yang mengelola objek wisata Sukageuri View, Taman Cisantana, Curug Suwer, Pengelolaan PAM dan Warung BUMDes (Kuningan, 2019)

Berdasarkan pasal 31 (Peraturan Menteri Desa, Pembangunan, Daerah Tertinggal, Dan Transmigrasi Nomor 4 Tahun 2015 Tentang Pendirian, Pengurusan Dan Pengelolaan, Dan Pembubaran Badan Usaha Milik Desa, 2015) menyatakan bahwa BUMDes mempertanggungjawabkan kinerjanya kepada Kepala Desa. BPD mengawasi Kepala Desa dalam membina BUMDes dan Pemerintah Desa mempertanggungjawabkan pembinaan BUMDes kepada Musyawarah Desa.

Pertanggungjawaban ini tentu saja termasuk pertanggungjawaban keuangan yang disampaikan dalam bentuk laporan keuangan. 
Saat ini aturan akuntansi untuk BUMDES mengacu pada SAK EMKM atau SAK ETAP yang disesuaikan dengan berapa besar aset yang dimiliki oleh BUMDes.

\section{Akuntansi untuk BUMDes}

Standar akuntansi yang berlaku di Indonesia ada empat. Pertama, SAK Umum, yang harus ditaati oleh perusahaan yang menjual sahamnya secara terbuka ke masyarakat. Kedua, SAK Entitas Tanpa Akuntabilitas Publik (ETAP) adalah standar akuntansi untuk perusahan yang tidak menjual sahamnya secara terbuka. Ketiga SAK Entitas Mikro, Kecil dan Menengah (EMKM) adalah peraturan akuntansi untuk usaha bisnis berskala mikro, kecil dan menengah. Keempat adalah SAK Syariah mengatur perlakuan akuntansi untuk transaksi yang berdasarkan hukum syariah.

SAK ETAP menyatakan bahwa laporan keuangan untuk perusahaan yang tergolong ETAP harus menyusun laporan keuangan yang terdiri dari Laporan Posisi Keuangan, Laporan Laba Rugi, Laporan Laba Ditahan, Laporan Arus Kas dan Catatan Atas Laporan Keuangan. Laporan-laporan ini disusun dengan dasar akrual dan menggunakan pengukuran biaya historis dan nilai wajar. SAK EMKM mengatur bahwa UMKM harus menyusun tiga jenis laporan keuangan, yaitu Laporan Posisi Keuangan, Laporan Laba Rugi dan Catatan Atas Laporan Keuangan. Laporan keuangan tersebut juga disusun berdasarkan dasar akrual dengan menggunakan pengukuran biaya historis.

Akuntansi untuk BUMDes tidak memakai Standar Akuntansi Pemerintahan, namun harus memakai SAK. Oleh sebab itu, SAK apa yang harus digunakan oleh BUMDes untuk menyusun laporan keuangannya, disesuaikan dengan karakteristik BUMDes itu sendiri. Jika BUMDes tersebut dikategorikan dalam usaha mikro, kecil dan menengah, maka BUMDes harus menyusun laporan keuangannya berdasarkan SAK EMKM, dan seterusnya. Dengan demikian BUMDes harus sudah selayaknya mengikuti ketentuan dari SAK ETAP atau SAK EMKM, yang disesuaikan dengan karakteristik BUMDes tersebut, untuk menyusun laporan keuangannya. Selanjutnya, laporan keuangan tersebut disampaikan kepada Kepala Desa sesuai dengan ketentuan PP NO. 4 tahun 2015.
Penelitian ini mengambil rumusan masalah mengapa sebuah BUMDes belum dapat menerapkan akuntansi yang sesuai dengan standar akuntansi. Dalam menjawab rumusan masalah tersebut, penelitian ini menggunakan metode studi kasus agar bisa menjelaskan secara detail kondisi apa yang menyebabkan sebuah BUMDes tidak mampu menerapkan akuntansi sesuai dengan peraturan yang berlaku.

Tujuan penelitian ini untuk menggali lebih dalam tentang latar belakang, peristiwa atau kejadian, dan objek apa yang menjadi penghambat akuntansi di sebuah BUMDes, sehingga dapat memberikan pemahaman yang luas tentang apa saja yang menjadi penghalang praktek akuntansi yang sesuai dengan peraturan. Diharapkan penelitian ini bisa memperluas wacana praktek akuntansi di BUMDes dan memberikan pelajaran yang berguna bagi BUMDes lain dalam memajukan praktek akuntansinya.

\section{Penelitian Terdahulu}

Penggunaan dana desa untuk diinvestasikan pada BUMDes ditujukan untuk meningkatkan ekonomi desa. Menurut Nugrahaningsih et al.(2016) ketersediaan modal BUMDes akan dapat terjaga dengan adanya dana desa sehingga proses penguatan ekonomi desa melalui BUMDes diharapkan akan lebih berdaya guna. Lebih jauh, keberadaan BUMDes diharapkan dapat meningkatkan pendapatan asli desa. Studi yang dilakukan oleh Irawati \& Martanti (2018) di BUMDes di Blitar memperlihatkan terdapat hubungan finansial antara pemerintah desa dengan BUMDes, yaitu BUMDes memberikan pinjaman kepada pemerintah desa untuk membeli tanah desa.

Hasil yang diharapkan dari keberadaan BUMDes adalah adanya peningkatan perekonomian masyarakat desa. Studi yang dilakukan oleh Anggraeni (2016) di tiga desa di Kabupaten Gunung Kidul dan Bantul memperlihatkan bahwa dengan adanya BUMDes terjadi peningkatan pendapatan asli desa, namun pendapatan ini tidak dapat dirasakan langsung oleh masyarakat. Hal ini menyebabkan warga berpendapat bahwa keberadaan BUMDes tidak membawa manfaat signifikan bagi peningkatan kesejahteraan warga. Namun studi oleh Kirowati \& Setia (2018) menyatakan bahwa pengembangan BUMDes di Kabupaten Magetan memberikan 
manfaat kepada masyarakat desa dengan menciptakan usaha baru, penyerapan tenaga kerja melalui pembangunan ekonomi desa. Dengan demikian, tesis bahwa keberadaan BUMDes untuk kesejahteraan masyarakat masih belum homogen.

BUMDes

berkewajiban mempertanggungjawabkan kinerjanya baik di depan perangkat desa serta masyarakat desa. Laporan keuangan merupakan salah satu media untuk cara pertanggungjawaban keuangann BUMDes. Studi di BUMDes di Kabupaten Wonogiri menghasilkan temuan bahwa pengelola wajib menyusun laporan pertanggungjawaban untuk disampaikan dalam forum musyawarah desa yang menghadirkan elemen pemerintahan desa, elemen masyarakat serta seluruh kelengkapan struktur organisasi BUMDes (Nugrahaningsih et al., 2016). Namun, penelitian tersebut juga menemukan bahwa masyarakat kurang antusias dalam berpartisipasi untuk meningkatkan kinerja BUMDes yaitu rendahnya partisipasi masyarakat dalam implementasi program kerja BUMDes, dan keterbatasan pengetahuan masyarakat tentang pembuatan rencana kerja dan laporan keuangan BUMDes (Nugrahaningsih et al., 2016).

Beberapa studi tentang BUMDes yang dimuat dalam jurnal akademik memperlihatkan bahwa terdapat BUMDes yang sudah membuat laporan keuangan sederhana. Contohnya BUMDes Karangbendo, Blitar yang melakukan pencatatan atas pendapatan dan pengeluaran dengan dasar kas (Irawati \& Martanti, 2018). Demikian juga BUMDes di Kabupaten Langkat yang juga memiliki pencatatan dan pelaporan akuntansi, namun belum diselenggarakan secara rapi dan sistematis (Erlina \& Sirojuzilam, 2020).

Berdasarkan hasil penelitian terdahulu, masih banyak peluang untuk meneliti aplikasi praktek akuntansi di BUMDes. Terutama studi yang menjelaskan mengapa BUMDes belum mampu menyusun laporan keuangan berdasarkan standar akuntansi. Oleh sebab itu, penelitian ini mengambil tema tersebut.

Penelitian ini mengambil kasus sebuah BUMDes yang belum bisa menyusun laporan keuangan berdasarkan standar akuntansi yang berlaku. Kasus yang digunakan dalam penelitian ini adalah BUMDes WM di sebuah desa di Jawa
Barat. BUMDes WM ini masih dalam tahap perkembangan sehingga penelitian ini bisa menjelaskan kondisi apa saja yang menghambat implementasi akuntansi berbasis standar akuntansi.

\section{Kerangka Teori}

Penelitian ini memakai teori modal sebagai kerangka untuk menganalisis data. Bourdieu (1986) menyatakan bahwa posisi individu atau organisasi dalam lingkungan sosial tergantung dari kepemilikan dan kemampuan mereka dalam mengelola modal (capital). Modal dapat berupa objek atau barang maupun sesuatu yang melekat pada tubuh manusia (pikiran, kepandaian, kesehatan). Modal digunakan sebagai bahan utama untuk mendapatkan keuntungan dan modal direproduksi agar menjadi semakin banyak dan berkembang. Proses untuk mengakumulasi modal membutuhkan waktu yang lama.

Ada tiga tipe modal yang utama, yaitu modal ekonomi, modal budaya dan modal sosial (Bourdieu, 1986). Modal ekonomi berkaitan dengan moneter, barang ekonomi seperti properti, kekayaan dan barang-barang lainnya yang bersifat finansial. Modal ekonomi adalah akar dari semua bentuk modal lainnya.

Modal budaya dapat berupa tiga bentuk, yaitu bentuk yang melekat pada tubuh manusia (pemikiran, kepandaian); dalam bentuk objek (instrumen, mesin, buku); dan dalam bentuk institusi (sistem sekolah, kualifikasi pendidikan).

Modal sosial adalah sumber daya yang berhubungan dengan kepemilikan jaringan dengan pihak lain. Jaringan sosial ini berasal dari interaksi sosial yang dapat berupa partisipasi di dalam masyarakat, organisasi atau orang lain atau kerjasama dengan pihak luar.

Kedudukan atau posisi sesorang atau organisasi ditentukan oleh bentuk, distribusi dan jumlah modal yang dimiliki oleh individu atau organisasi dalam lingkungan sosial. Bentuk, distribusi dan jumlah modal antara individu atau organisasi satu dengan yang lain tentulah tidak merata sehingga hal ini menimbulkan peringkat status sosial dalam lingkungan masyarakat.

Berdasarkan kondisi atas kepemilikan modal yang ditinjau dari aspek bentuk, distribusi dan 
jumlah, maka individu atau organisasi itu mempunyai kekuatan di lingkungan tempat ia berada. Kekuatan tersebut digunakan untuk mempertahankan posisi atau meraih posisi sehingga ia mendapat pengakuan dari masyarakat. Dampak dari pengakuan tersebut adalah, salah satunya, penambahan modal yang dimilikinya (symbolic capital).

Oleh sebab itu, kondisi kepemilikan modal yang tidak cukup akan mengakibatkan keterbatasan dalam melakukan sesuatu termasuk dalam meraih posisi dalam lingkungan sosial. Sebaliknya, dengan modal yang cukup maka individua tau organisasi akan mempunyai kekuatan dalam melakukan sesuatu, termasuk kekuatan untuk meraih posisi atau mempertahankan posisi di lingkungan sosialnya.

Kesuksesan individu atau organisasi dalam menjalan praktek tertentu merupakan cerminan dari keberhasilan mereka dalam mengakumulasi modal. Hasil dari praktek yang mereka lakukan adalah tercapainya posisi yang diinginkannya serta ketercapaian tersebut mendapat pengakuan dari lingkungan masyarakatnya.

Misalnya, sebuah perusahaan berhasil menyusun laporan keuangan berdasarkan standar akuntansi, karena ia mempunyai modal berupa sistem akuntansi, staf akuntansi dan jaringan dengan konsultan bisnis. Laporan keuangan yang sudah jadi ia sampaikan kepada investor dan kreditor sehingga perusahaan mampu mendapatkan tambahan dana. Dengan dana segar yang didapat, perusahaan dapat mempertahankan kinerjanya sehinga posisi perusahaan akan tetap kuat di dunia perindustrian dimana perusahaan tersebut berada.

Berangkat dari pemikiran (Bourdieu, 1986) ini, maka penelitian ini menggali bagaimana kondisi kepemilikan tiga tipe modal pada sebuah BUMDes dalam kaitannya untuk mempraktekakan akuntansi yang sesuai dengan standar. Penelitian ini berasumsi bahwa tiga tipe modal inilah yang mempengaruhi kemampuan atau ketidakmampuan BUMDes dalam mengaplikasikan akuntansi yang sesuai dengan standar yang berlaku.

\section{METODE PENELITIAN}

Penelitian ini menggunakan metode studi kasus eksplanatoris. Metode ini sesuai dengan bentuk pertanyaan penelitian "mengapa" (Yin, 2015). Studi kasus eksplanatoris digunakan karena penelitian ini ingin memahami secara mendalam dan dari dekat mengapa implementasi akuntansi di BUMDes belum dapat dilakukan. Kasus yang diambil adalah belum mampunya BUMDes WM di sebuah desa di Jawa Barat, untuk mengimplementasikan akuntansi sesuai dengan standar akuntansi. Selain itu, penelitian ini juga akan mencari kondisi apa saja yang menjadi penghalangnya yang ditinjau dari tiga tipe modal.

Pendekatan kualitatif dipakai, karena penelitian tidak mencari hubungan yang saling mempengaruhi antara variabel. Namun penelitian ini fokus pada apa yang benar-benar dialami, peristiwa apa yang menjadi penghambat bagi BUMDes WM untuk menerapkan akuntansi berdasarkan standar akuntansi. Hal ini sesuai dengan makna penelitian kualitatif yang disampaikan oleh Pietkiewicz \& Smith (2014).

Data penelitian diambil dengan cara wawancara, observasi dan dokumentasi. Wawancara dilakukan dengan Bendahara, Sekretaris BUMDes dan salah satu Kepala Unit Usaha. Hadir juga pada saat wawancara adalah Bendahara Desa dan Sekretaris Desa. Wawancara ditujukan untuk mencari tahu bagaimana pengelolaan BUMDes selama ini baik di bidang akuntansi dan manajemen. Wawancara didesain seperti diskusi antara peneliti dan pengelola BUMDes dan pemerintah desa.

Observasi juga dilakukan untuk mengetahui dan merasakan atas berjalannya kehidupan masyarakat desa, bisnis BUMDes dan hubungan BUMDes dengan masyarakat desa dan pemerintah desa. Observasi dilaksanakan selama tiga hari. Selain wawancara dan observasi, data juga diambil melalui dokumentasi yaitu buku kas masuk, buku kas keluar, buku bank, register penutupan kas dan daftar inventaris aset.

Hasil wawancara, observasi dan dokumentasi kemudian diolah dan dianalisa dengan pendekatan analisis interpretatif dengan 
kerangka teori modal dari Bourdieu (1986). Analisis interpretatif relevan digunakan, karena penelitian ini bertujuan memberikan wacana yang luas mencakup latar belakang, peristiwa atau kejadian, dan objek apa yang menjadi penghambat akuntansi di sebuah BUMDes.

Dengan demikian penelitian ini mendapatkan suatu pemahaman yang dalam tentang apa saja yang menghambat terjadinya praktek akuntansi yang sesuai dengan peraturan di BUMDes yang dijadikan sebagai studi kasus. Dengan analisa interpretatif ini, penelitian ini bisa memberikan solusi pragmatis yang bisa diterapkan oleh BUMDes. Hal ini sesuai dengan pemahaman analisa interpretatif yang dinyatakan oleh Pulakanam \& Suraweera (2010).

\section{HASIL DAN PEMBAHASAN}

BUMDes WM berada di sebuah desa kecil di Provinsi Jawa Barat. Desa tempat BUMDes WM, berada di sekitar lereng Gunung Cikuray sebelah barat dengan ketinggian $\pm 1200 \mathrm{dpl}$ (di atas permukaan laut). Desa ini memiliki wilayah 1.401. ha, yang terdiri dari 43 Rukun Tetangga (RT) dan 11 Rukun Warga (RW) yang terbagi menjadi Tiga Dusun. Sebagian besar wilayah desa merupakan lahan pertanian dan perkebunan teh. Jumlah penduduk desa kurang lebih 7.934 jiwa dengan mata pencaharian sebagian besar sebagai petani dan bekerja di perkebunan.

BUMDes WM didirikan oleh Pemerintah Desa pada tahun 2015, dengan modal awal didapat dari alokasi dana desa. BUMDes WM bergerak dalam bidang jasa persewaan gedung, sound system, tenda, kursi dan dekorasi. Pengelola BUMDes terdiri dari Komisaris, Badan Pengawas, Manajer, Sekretaris, Bendahara, Staf Administrasi dan Kepala Unit Usaha. Setiap periode BUMDes akan membagi hasil pengelolaan BUMDes kepada pemerintah desa sebagai pendapatan asli daerah.

Akuntansi dan keuangan BUMDes dikelola oleh Bendahara BUMDes. Pencatatan transaksi dilakukan dengan cara basis kas dengan mencatat seluruh kas masuk dan kas keluar di dalam buku kas umum. BUMDes WM juga mempunyai buku bank yang digunakan untuk mencatat segala transaksi yang dilakukan melalui bank, termasuk beban administrasi bank dan bunga bank.
Selama ini BUMDes WM belum menghitung jumlah keuntungan maupun kerugian yang didapat dengan menyusun Laporan Laba Rugi yang sesuai dengan standar akuntansi. Pembagian hasil keuntungan BUMDesa WM untuk kas Desa hanya berdasarkan jumlah kesepakatan antara pengelola BUMDes dengan Pemerintah Desa dengan mempertimbangkan ketersediaan jumlah kas yang dimiliki oleh BUMDes.

Selain itu manajemen BUMDes WM belum memiliki laporan posisi keuangan yang sesuai dengan standar akuntansi. Namun BUMDes WM sudah mempunyai buku inventarisasi untuk mencatat aset tetap yang dijadikan objek persewaan. Laporan pertanggungjawaban keuangan BUMDes WM disajikan dalam bentuk ringkasan buku kas umum dan buku bank di setiap akhir bulan. Laporan ini disampaikan kepada pengelola BUMDes sebagai pertanggungjawaban bendahara kepada manajemen.

Pengendalian kas dilakukan dengan cara melakukan pemeriksaan kas secara fisik oleh ketua BUMDes. Hasil pemeriksaan didokumentasikan dalam lembar Berita Acara Pemeriksaan Kas. Setiap akhir bulan juga disusun Register Penutupan Kas yang merupakan ringkasan jumlah kas masuk dan keluar selama satu bulan. Informasi lainnya dalam Register Penutupan Kas adalah jumlah fisik lembar dan keping uang dan jumlah nominal uang yang menunjukan saldo akhir bulan kas. Prosedur untuk penerimaan kas dan pengeluaran kas sudah ada namun masih sederhana karena memang perputaran modal BUMDesa juga masih sedikit.

Dari penjelasan diatas dapat diketahui bahwa BUMDes memang telah mempertanggungjawabkan keuangannya secara sederhana. BUMDes mencatat keluar masuknya kas dengan sistem tabelaris, mencatat inventaris dan melakukan kontrol atas kas. Namun, BUMDes belum mampu membuat Laporan Laba Rugi dan Laporan Posisi Keuangan sesuai dengan standar yang ada.

Selain data dokumentasi yang berkaitan dengan pencatatan akuntansi, penelitian juga mendapatkan data yang diperoleh dari wawancara dan observasi. Dari hasil wawancara dan observasi, penelitian ini menemukan 
terdapat beberapa permasalahan masalah dalam manajemen BUMDes WM yaitu (1) masalah permodalan; (2) kepemilikan aset; dan (3) masalah sumber daya manusia.

Pertama, modal BUMDes WM sangat tergantung dengan dana alokasi dari APBDesa. Modal awal BUMDes memang dari APBDesa. Namun, BUMDes tetap menerima dana alokasi dari anggaran desa setiap tahunnya, dikarenakan BUMDes belum cukup mampu dalam mengakumulasikan modal moneter melalui hasil pendapatan BUMDes. Jadi kemandirian finansial BUMDes belum tercapai.

Dana anggaran desa yang dialokasikan oleh pemerintah desa merupakan investasi pemerintah desa. BUMDes diharapkan dapat memberikan hasil pengembalian investasi berupa pembagian hasil usaha yang dibagi antara BUMDes dan pemerintah desa berdasarkan jumlah pendapatan BUMDes. Kesepakatan ini sudah berjalan dengan baik dan BUMDes sudah menyetorkan bagi hasil tersebut ke kas desa, meskipun jumlahnya belum signifikan.

Namun selama ini, kesepakatan tentang jumlah bagi hasil antara BUMDes dan pemerintah desa ini tidak ditentukan di awal periode dan tidak berupa kesepakatan tertulis. Demikian juga, BUMDes tidak memiliki target penghasilan yang harus dicapai dalam satu periode.

Tidak adanya target pencapaian hasil ini mungkin memicu BUMDes WM kurang termotivasi dalam mengelola kekayaannya sehingga perputaran modal moneternya menjadi kurang lancar. Sebagai akibatnya BUMDes WM akan menunggu alokasi anggaran desa lagi untuk menambah modal moneternya. Dengan demikian ketergantungan modal moneter pada anggaran desa akan terjadi terus menerus, selama kemampuan bisnis dan manajemen BUMDes tidak berubah.

Masalah kedua menyangkut kepemilikan aset. BUMDes sudah mempunyai daftar aset tetap yang digunakan untuk mendapatkan penghasilan. Dalam daftar inventaris sudah ada keterangan bagaimana aset tersebut diperoleh dan sebagian besar pengadaan aset tetap BUMDes dibeli dengan dana dari pemerintah desa. Jadi, aset BUMDes diperoleh dengan menggunakan dana APBDes, namun aset tersebut digunakan untuk kepentingan BUMDes dalam mencari penghasilannya. Misalnya kursi yang untuk disewakan oleh BUMDes, dibeli dengan dana anggaran desa, namun hasil sewa kursi dimasukkan sebagai penghasilan BUMDes.

Masalah aset yang dibeli dengan dana APBDes jelas merupakan masalah ketergantungan modal juga. Namun, masalah ini menimbulkan masalah kedua yaitu pihak siapa yang menjadi pemilik aset tetap, karena kepemilikan aset menimbulkan konsekuensi perlakuan akuntansi atas aset tersebut. Kembali kepada contoh masalah kursi tadi, maka siapakah pihak yang memiliki kursi, karena faktor kepemilikan inilah yang menentukan perlakuan akuntansi atas kursi.

Solusi yang mungkin dapat diambil untuk permasalahn ini adalah harus ada kesepakatan antara BUMDesa dan pemerintah desa tentang kepemilikan aset ini. Setiap opsi yang dipilih tentu harus diikuti dengan konsekuensi perlakukan akuntansinya. Sebagai contoh, jika aset diakui sebagai aset milik BUMDes, maka BUMDes harus mencatat sebagai tambahan modal pemerintah desa ke BUMDes. Jika, aset dimiliki oleh pemerintah desa, maka harus ada nota kesepakatan atau berita acara yang menandakan bahwa BUMDes berhak menggunakan aset tersebut untuk menjalankan proses bisnisnya. Dengan demikian, akuntansi dapat membantu memperjelas hak dan kewajiban masing-masing pihak.

Permasalahan ketiga adalah masalah kompetensi manajerial pengelola BUMDesa yang masih terbatas. Kemampuan manajemen dan akuntansi mereka belum cukup untuk mengelola BUMDesa secara profesional. Sebagian besar pengelola BUMDesa bekerja di kebun dan belum berpendidikan tinggi. Bendahara BUMDesa mendapat ketrampilan pembukuan berasal dari pengelola lain yang memiliki pendidikan lebih tinggi, sehingga ketrampilan akuntansi dan pembukuannya belum optimal.

Berdasarkan data yang diperoleh terkait dengan pencatatan akuntansi yang sederhana dan sistem pelaporan keuangan yang hanya berupa saldo kas saja menunjukkan pemahaman BUMDes terhadap akuntansi masih sederhana. Dengan demikian, praktek akuntansi yang mengacu pada 
standar akuntansi masih jauh dari pemikiran mereka.

Berdasarkan data yang diperoleh maka dapat dilihat bahwa (1) kemampuan akuntansi di BUMDes masih lemah; (2) terdapat faktor ketergantungan modal; (3) dan terbatasnya kemampuan professional sumber daya manusia BUMDes. Mengikuti alur teori modal Bourdieu (1986), ketiga permasalahan diatas tadi merupakan cerminan dari terbatasnya kepemilikan tiga tipe modal, sehingga praktek akuntansi yang diterapkan belum sesuai dengan standar yang berlaku.

Pertama adalah keterbatasan modal ekonomi yaitu berupa modal moneter yang masih tergantung dengan dana APBDes. Kedua keterbatasan modal budaya dimana pengurus BUMDes belum kompeten dalam bidang manajemen dan akuntansi. Serta, akuntansi yang dilaksanakan secara manual dan menggunakan tabelaris menandakan BUMDes belum mempunyai sistem akuntansi yang sistematis.

Keterbatasan modal budaya ini juga bisa disebabkan karena lokasi BUMDes sangat jauh dari pusat kota, kehidupan disana masih sangat sederhana dan kebiasaan yang dilakukan oleh penduduk desa juga dilakukan secara turunmenurun. Misalnya, jika orang tua bekerja di perkebunan maka anaknya kemungkinan besar akan bekerja di perkebunan juga. Berdasarkan observasi, penelitian ini juga melihat bahwa kemampuan inovasi masyarakat disana juga masih rendah. Sebagai contoh desa ini mempunyai kemampuan besar di bidang perkebunan, namun mereka belum mampu mengolah hasil kebun menjadi produk konsumsi yang mempunyai daya jual.

Hal ini juga terlihat bahwa kebiasaan akuntansi BUMDes juga dilakukan secara turun-menurun, dimana bendahara yang baru meneruskan perlakuan akuntansi dari pihak sebelumnya. Hal ini juga ditambah dengan keterbatasan pengetahuan dan ketrampilan, sehingga perkembangan dan kegunaan akuntansi belum sempurna pengaplikasiannya. Sebagai contoh, BUMDes sudah mempunyai informasi berupa daftar inventaris, namun informasi ini belum digunakan secara maksimal sebagai keputusan untuk mengembangkan bisnis BUMDes. Dengan kata lain, manajemen BUMDes masih jauh dari profesionalisme dan kompeten meskipun, BUMDes sudah berjalan selama kurang lebih lima tahun.

Dari hasil observasi juga, penelitian ini melihat bahwa pihak pemerintah desa memang sebagai pemilik modal yang paling besar. Pemerintah desa memiliki APBDes yang menjadi pemasok utama pendanaan BUMDes. Pemerintah Desa juga mempunyai modal budaya karena mempunyai kepala desa dengan pendidikan yang tinggi dan perangkat desa yang juga mempunyai pendidikan tinggi. Di lain pihak BUMDes belum sepenuhnya diisi dengan orang-orang yang mempunyai pendidikan tinggi.

BUMDes WM juga belum mempunyai jaringan dengan pihak luar yang bisa mentransfer ilmu akuntansi kepada mereka. Hal ini mungkin disebabkan karena lokasi desa yang terletak di lereng gunung dan jauh dari pusat kota, sehingga akses dari dan ke luar desa masih sulit. Namun masalah ini sebetulnya bisa diatasi dengan komunikasi dengan media digital dengan pihak luar.

BUMDes WM juga belum optimal mengakumulasikan modalnya. Hal ini dapat dilihat bahwa BUMDes belum mampu mempunyai pendapatan yang bisa membuat BUMDes mandiri secara finansial. Dengan demikian ukuran kekayaan BUMDes juga masih kecil.

Kemudian, staf BUMDes masih belum optimal juga dalam mengembangkan ketrampilan dan kompetensinya di bidang akuntansi. Ditambah lagi dengan kondisi ketiga yaitu kurangnya interaksi BUMDes dengan pihak luar di bidang transfer ketrampilan manajemen dan akuntansi masih terbatas.

Berdasarkan hasil analisa, studi ini menginterpretasikan bahwa BUMDes WM belum mampu melaksanakan praktek akuntansi yang sesuai dengan peraturan yang berlaku karena kondisi keterbatasan atas tiga tipe modal tadi. Dengan kata lain, ketiga keterbatasan atas modal inilah yang menjadi penghambat bagi berkembangnya praktek akuntansi yang sesuai dengan peraturan di BUMDes.

Hasil analisa selanjutnya adalah menemukan bahwa posisi BUMDes masih lemah di lingkungan sosial desa tempat BUMDes berada. 
Dibanding dengan pemerintah desa, kekuatan BUMDes masih berada dibawahnya. Hal ini disebabkan karena pemerintah desa sebagai unsur utama dalam pembiayaan BUMDes ditambah lagi pemerintah desa dengan perangkatnya yang berpendidikan tinggi. Dengan demikian dapat diartikan BUMDes masih belum bisa menjadi mitra pemerintah desa untuk melaksanakan pemberdayaan ekonomi desa.

Pemerintah desa tempat studi kasus ini dilaksanakan, mendirikan BUMDesa sebagai upaya untuk memajukan ekonomi dan kesejahteraan masyarakat desa melalui usaha yang dimodali oleh APBDesa. Namun, keberlanjutan BUMDes sebagai partner pemerintah desa dalam melaksanakan pemberdayaan ekonomi desa bisa terancam jika faktor ketergantungan modal dengan pemerintah desa tidak teratasi. BUMDes harus berusaha mendapatkan dan mengakumulasi ketiga jenis modal tadi, yaitu menambah keuntungan bisnis dan memperoleh pengetahuan akuntansi dan manajemen. Kerjasama dengan pihak luar bisa digunakan sebagai cara untuk mendapatkan dua jenis modal utama yaitu uang dan pengetahuan.

Akuntansi bisa membantu keberlangsungan BUMDes. Sebagai awal, perlakuan akuntansi yang benar bisa dicapai jika BUMDes memperoleh pengetahuan yang memadai tentang akuntansi. Pengetahuan ini bisa didapat dengan mendapatkan jejaring kerjasama dengan pihak lain, misalnya perguruan tinggi atau pemerintah kabupaten. Dengan pengetahuan akuntansi dan manajemen, BUMDes bisa menerapkan akuntansi yang sesuai dengan peraturan dan dampaknya bisa membuat rencana pengembangan bisnisnya. Tentu saja implementasi akuntansi harus diselaraskan dengan ukuran BUMDes sehingga perbandingan antara biaya dan manfaatnya seimbang.

Kondisi BUMDes yang dijadikan studi kasus ini berbeda kondisinya dengan studi tentang akuntansi BUMDes sebelumnya. Saat ini, pencatatan transaksi yang dilakukan oleh BUMDesa tempat studi kasus ini dilaksanakan masih sederhana dan belum bisa menyusun laporan keuangan. Hal ini berbeda dengan keadaan BUMDes yang sudah pernah diteliti sebelumnya, dimana BUMDes sudah mampu menyusun laporan keuangan (Erlina \&
Sirojuzilam, 2020; Irawati \& Martanti, 2018; Nugrahaningsih et al., 2016)

Hasil studi ini juga bertentangan dengan hasil penelitian Kirowati \& Setia (2018), dimana mereka menemukan bahwa BUMDes sudah mampu memberikan manfaat kepada masyarakat. Studi ini belum melihat adanya nilai tambah bagi masyarakat desa. Masyarakat masih belum merasakan manfaat ekonomi dari keberadaan BUMDesa. Hal ini masih jauh dari harapan dari adanya keikutsertaan masyarakat dalam memodali BUMDesa.

\section{KESIMPULAN}

BUMDes belum mampu menerapkan akuntansi yang sesuai dengan peraturan yang berlaku. Hal ini disebabkan karena BUMDes belum mampu mengakumulasi modal yang berguna untuk melaksanakan praktek akuntansi yang sesuai dengan standar yang berlaku.

Studi ini menginterpretasikan bahwa keterbatasan praktek akuntansi yang dilaksanakan oleh BUMDes ini dikarenakan adanya keterbatasan kepemilikan tiga jenis modal. Pertama, modal keuangan BUMDes masih tergantung dengan pemerintah desa. Kedua, modal budaya berupa pengetahuan, ketrampilan dan sistem akuntansi yang merujuk pada praktek akuntansi berbasis standar akuntansi belum dimiliki. Ketiga adalah, keterbatasan modal sosial juga belum dimiliki. Padahal dengan modal sosial, BUMDes bisa menambah modal finansial selain dari anggaran desa dan membawa pengetahuan akuntansi masuk ke BUMDes

Dengan keterbatasan tiga jenis modal ini, akuntansi tidak berkembang dan manajemen keuanganpun belum bisa dijalankan. BUMDes sampai saat ini masih belum bisa mandiri secara finansial dan belum bisa menyumbangkan pendapatan asli desa secara signifikan kepada pemerintah desa. Dengan demikian posisi BUMDes masih belum bisa menjadi partner aktif bagi pemerintah desa dalam melaksanakan program pemberdayaan desa.

Saran untuk praktek akuntansi bagi BUMDes ini adalah, hendaknya BUMDes segera membenahi sistem akuntansinya yang merujuk pada standar 
akuntansi EMKM. Diharapkan dengan hal tersebut, BUMDesa bisa menyusun laporan keuangan yang sesuai dengan standar akuntansi.

Jika demikian keadaannya, maka alur keuangan bisa dengan jelas ditelusuri dari penerimaan sampai pengeluaran dan pertanggungjawaban keuangan bisa juga secara transparan dilakukan melalui laporan keuangan yang sesuai dengan standar akuntansi. Selain itu, dengan adanya laporan keuangan, BUMDesa bisa mendapatkan peluang dalam mengakses pendanaan berupa kredit mikro dari pihak selain dari anggaran desa.

Pengelolaan BUMDesa yang masih belum professional dan kompeten sebaiknya mulai dibenahi. Kebutuhan akan pengetahuan manajemen lainnya juga dibutuhkan BUMDes untuk mengembangkan bisnisnya, seperti antara lain, penyusunan anggaran, target kinerja BUMDesa dan strategi pencapaiannya. Pengetahuan manajemen ini bisa membantu pengelola BUMDes agar fokus terhadap hasil dan tujuan BUMDes yang ingin diraih. Oleh sebab itu dibutuhkan pemimpin dan pengurus BUMDes sebaiknya mempunyai sikap entrepreneurship, leadership dan kreatif.

Kemitraan dengan pihak lain, misal dengan perguruan tinggi maupun organisasi profesional, sangat diperlukan untuk membenahi pengelolaan akuntansi dan manajemen BUMDesa. Pengabdian masyarakat oleh perguruan tinggi hendaknya menjadi alih pengetahuan dan teknologi agar BUMDesa bisa mandiri secara finansial.

Program kerjasama yang bisa dilakukan BUMDesa dengan menjalin kemitraan dengan perguruan tinggi maupun organisasi profesi adalah program yang ditujukan untuk meningkatkan profesionalisme manajemen BUMDesa. Misalnya adalah dengan membantu membuat strategi manajemen BUMDesa, menyusun anggaran, penyusunan pedoman sistem akuntansi, pendampingan penyusunan laporan keuangan, atau yang lainnya. Kemitraan ini tentunya akan memberikan keuntungan di kedua belah pihak. Dengan demikian, hubungan kerjasama dengan pihak eksternal ini diharapkan bisa menaikkan kemampuan BUMDes agar bisa menjadi motivator masyarakat desa untuk lebih giat dalam mencari peluang bisnis supaya ekonomi masyarakat desa meningkat.

\section{REFERENSI}

Anggraeni, M. R. R. S. (2016). Peranan Badan Usaha Milik Desa (Bumdes) Pada Kesejahteraan Masyarakat Pedesaan Studi Pada Bumdes Di Gunung Kidul, Yogyakarta. Modus Journals, 28(2).

Aryadjihs. (2017). Ini Dia Lima Bumdes Terbaik Di Pulau Jawa. Https://Www.Berdesa.Com/Ini-Dia-LimaBumdes-Terbaik-Di-Pulau-Jawa/

Bourdieu, P. (1986). The Forms Of Capital. In The Sociology of Economic Life, Third Edition (Pp. 1-543). Https://Doi.Org/10.4324/9780429494338

Erlina, E., \& Sirojuzilam, S. (2020). Efektivitas Penerapan Sistem Pencatatan Dan Pelaporan Keuangan Bumdes Sistem Akuntansi Bumdes Berbasis Web. Owner, 4(1), 282. Https://Doi.Org/10.33395/Owner.V4i1.195

Indonesia, K. K. B. P. M. Dan K. R. (2020). 2020, Dana Desa Fokus Pada Pemberdayaan Masayarakat Dan Pengembangan Potensi Ekonomi Desa. Https://Www.Kemenkopmk.Go.Id/2020Dana-Desa-Fokus-Pada-PemberdayaanMasayarakat-Dan-Pengembangan-PotensiEkonomi-Desa

Irawati, D., \& Martanti, D. E. (2018). Transparansi Pengelolaan Laporan Keuangan Bumdes Terhadap Pelaporan Aset Desa (Studi Fenomenologi Pada Bumdes Desa Karangbendo Kec Ponggok Kab Blitar). Seminar Nasional Ekonomi Dan Bisnis (Snaper-Ebis 2017) Fakultas Ekonomi Dan Bisnis Universitas Jember, 41-51.

Peraturan Menteri Desa, Pembangunan, Daerah Tertinggal, Dan Transmigrasi Nomor 4 Tahun 2015 Tentang Pendirian, Pengurusan Dan Pengelolaan, Dan Pembubaran Badan Usaha Milik Desa, (2015).

Kirowati, D., \& Setia, L. D. (2018). Pengembangan Desa Mandiri Melalui Bumdes Dalam Meningkatkan Kesejahteraan Masyarakat Desa ( Studi Kasus :Desa Temboro Kecamatan Karas Kabupaten Magetan). Jurnal AKSI (Akuntansi Dan Sistem Informasi), 2(1), 1524. https://doi.org/10.32486/aksi.v2i1.213

Kuningan, P. K. (2019). BUMDes Desa 
Cisantana Jadi Yang Terbaik Di Jawa Barat. https://www.kuningankab.go.id/berita/bumd es-desa-cisantana-jadi-yang-terbaik-di-jawabarat

Nugrahaningsih, P., Falikhatun, F., \& Winarna, J. (2016). Optimalisasi Dana Desa dengan Pengembangan Badan Usaha Milik Desa (BUM Des) Menuju Desa Mandiri. Jurnal Akuntansi Dan Bisnis, 16(1).

Pietkiewicz, I., \& Smith, J. A. (2014). A practical guide to using Interpretative Phenomenological Analysis in qualitative research psychology. Czasopismo Psychologiczne Psychological Journal, 20(1). https://doi.org/10.14691/cppj.20.1.7

Pulakanam, V., \& Suraweera, T. (2010). Implementing Accounting Software In Small Businesses In New Zealand: An Exploratory Investigation. Accountancy Business and the Public Interest, 9(64), 98-124.
Purnomo, B. (2018). Keren, BUMDES Ujunggebang Terbaik ke-2 di Jawa Barat. https://indramayukab.go.id/keren-bumdesujunggebang-terbaik-ke-2-di-jawa-barat/

Viska. (2017). Melalui Nawacita, Pemerintah Berkomitmen Bangun Desa. Indonesia, Kementerian Komunikasi Dan Informatika Republik.

https://kominfo.go.id/content/detail/9545/m elalui-nawacita-pemerintah-berkomitmenbangun-desa/0/berita

Yin, R. K. (2015). Studi Kasus Desain \& Metode (1st ed.). Rajawali Pers. 